\title{
PEMBANGUNAN RUANG TERBUKA HIJAU KAWASAN PERKOTAAN
}

\author{
Oleh : Dr. Ida Farida, S.H., M.H. ${ }^{*}$
}

\begin{abstract}
ABSTRAKS
Ruang terbuka hijau membawa begitu banyak manfaat yang terkandung. Mulai dari sarana untuk mencerminkan identitas daerah, menumbuhkan rasa bangga dan meningkatkan prestise daerah, sarana ruang evakuasi untuk keadaan darurat, sebagai sarana penelitian, pendidikan dan penyuluhan, memperbaiki iklim mikro hingga meningkatkan cadangan oksigen di perkotaan dan tak ketinggalan bermanfaat bagi meningkatkan nilai ekonomi lahan perkotaan. Bahkan terkandung pula manfaat yang lebih bernilai sosial seperti sebagai sarana rekreasi aktif dan pasif serta interkasi sosial atau sebagai sarana aktivitas sosial bagi anak-anak, remaja, dewasa dan manula. Bisa dibilang kebutuhan akan adanya ruang semacam ini di kota-kota besar tak hanya sekedar perlu namun kebutuhan.

Kata Kunci : Pentingnya Ruang Terbuka Hijau Kota

\section{ABSTRAKS}

Green open spaces bring so many benefits contained. Starting from the facility to reflect the regional identity, develop a sense of pride and enhance the prestige of the area, means chamber evacuation for emergencies, as a means of research, education and extension, improve the micro-climate to increase the oxygen reserves in urban areas and do not miss the benefit to increase the economic value of urban land, In fact, also contained a more socially valuable benefits such as active and passive recreation and social interaction or as a means of social activities for children, teens, adults and seniors. Arguably the need for this kind of space in big cities is not just a need but a necessity.
\end{abstract}

Keywords : Importance of Green Open Space City.

\section{A. PENDAHULUAN}

Pemanfaatan ruang masih belum sesuai dengan harapan yakni terwujudnya ruang yang nyaman, produktif dan berkelanjutan. Menurunnya kualitas permukiman di perkotaan dapat dilihat dari kemacetan yang semakin parah, berkembangnya kawasan kumuh yang rentan dengan bencana banjir serta semakin hilangnya ruang terbuka (openspace) yang berfungsi ekologis yaitu dapat meningkatkan kualitas air tanah, mencegah banjir, mengurangi polusi udara dan pengatur iklim mikro. Fungsi lainnya yaitu sosial ekonomi untuk memberikan fungsi sebagai ruang interaksi sosial, sarana rekreasi dan kesehatan masyarakat.

Sebagai wahana interaksi sosial,

\footnotetext{
*) Dosen Tetap Fakultas Hukum Universitas Galuh
} 
ruang terbuka diharapkan dapat mempertautkan seluruh anggota masyarakat tanpa membedakan latar belakang sosial, ekonomi, dan budaya. Aktivitas di ruang publik dapat bercerita secara gamblang seberapa pesat dinamika kehidupan sosial suatu masyarakat.

Ruang terbuka menciptakan karakter masyarakat kota. Tanpa ruangruang publik masyarakat yang terbentuk adalah masyarakat maverick yang nonkonformis-individualis-asosial, yang anggota-anggotanya tidak mampu berinteraksi apalagi bekerja sama satu sama lain. Agar efektif sebagai mimbar, ruang publik haruslah netral. Artinya, bisa dicapai (hampir) setiap penghuni kota. Tidak ada satu pun pihak yang berhak mengklaim diri sebagai pemilik dan membatasi akses ke ruang publik sebagai sebuah mimbar politik.

Ruang terbuka adalah ruang yang bisa diakses oleh masyarakat baik secara langsung dalam kurun waktu terbatas maupun secara tidak langsung dalam kurun waktu tidak tertentu. Ruang terbuka itu sendiri dapat berbentuk jalan, trotoar, ruang terbuka hijau seperti taman kota, hutan, dan sebagainya.

Ruang-ruang terbuka atau ruangruang publik ditinjau dari bentuk fisiknya dapat rupa ruang terbuka hijau dan/atau ruang terbuka binaan (Publik atau Privat).

Secara definitif, ruang terbuka hijau (Green Openspaces) adalah kawasan atau areal permukaan tanah yang didominasi oleh tumbuhan yang dibina untuk fungsi perlindungan habitat tertentu, dan atau sarana lingkungan/kota, dan atau pengamanan jaringan prasarana, dan atau budidaya pertanian. Selain untuk meningkatkan kualitas atmosfer, menunjang kelestarian air dan tanah, Ruang Terbuka Hijau (Green Openspaces) di tengah-tengah ekosistem perkotaan juga berfungsi untuk meningkatkan kualitas lansekap kota.

Ruang terbuka hijau yang ideal adalah $30 \%$ dari luas wilayah. Hampir disemua kota besar di Indonesia, Ruang terbuka hijau saat ini baru mencapai $10 \%$ dari luas kota. Padahal ruang terbuka hijau diperlukan untuk kesehatan, arena bermain, olah raga dan komunikasi publik. Pembinaan ruang terbuka hijau harus mengikuti struktur nasional atau daerah dengan standar-standar yang ada.

Pasal 1 butir 31 Undang-Undang Nomor 26 Tahun 2007 tentang Penataan Ruang mengatur tentang istilah ruang terbuka hijau yang mengandung pengertian sebagai suatu area memanjang/jalur dan/atau 
mengelompok yang gunanya lebih bersifat terbuka, tempat tumbuh tanaman, baik yang tumbuh secara alamiah maupun yang sengaja ditanam.

Kegunaan ruang terbuka hijau ini dimaksudkan agar dapat menekan efek negatif yang ditimbulkan lingkungan terbangun di perkotaan, seperti peningkatan temperatur, penurunan tingkat peresapan air dan kelembaban udara, polusi dan lain sebagainya.

RTH sebagai area bermain, berolahraga, bersosialisasi dan aktivitas lainnya, RTH hijau ini berbentuk taman dan lapangan olah raga. Sesuai dengan Petunjuk Perencanaan Kawasan Perumahan Kota Ditjen Ciptakarya Departemen Pekerjaan Umum yang ditegaskan lagi dalam Pasal 9 ayat (1) Peraturan Menteri Dalam Negeri Nomor 1 Tahun 2007 tentang Penataan Ruang Terbuka Hijau di Wilayah Perkotaan, mensyaratkan tersedianya taman lingkungan dan taman kota sebagai berikut :

Luas ideal Ruang Terbuka Hijau Kawasan perkotaan minimal $20 \%$ dari luas kawasan perkotaan.

Pasal 67 huruf e Peraturan Pemerintah Nomor 15 Tahun 2010 tentang Penyelenggaraan Penataan Ruang berbunyi "Penyusunan rancangan peraturan daerah kabupaten tentang rencana tata ruang kawasan perkotaan yang menjadi bagian dari kabupaten yang dilaksanakan sesuai dengan ketentuan peraturan perundangundangan".

\section{B. PEMBAHASAN}

Dalam melaksanakan pembangunan menghadapi dua masalah besar yang tidak dapat dihindari yaitu jumlah penduduk dari tahun ke tahun terus meningkat, sehubungan dengan perbandingan antara presentase kelahiran dan kematian yang meningkat, dengan adanya peningkatan kesehatan yang semakin baik. Dipihak lain luas tanah tetap, bahkan ada kecenderungan perubahan penggunaan tanah yang semakin meningkat, sebagai akibat adanya peningkatan pembangunan fisik seperti terbentuknya daerah pemukiman, kawasan industri, keperluan olah raga seperti lapangan golf, dan lain-lain.

Apabila hal ini terus dibiarkan dan tidak dikendalikan, dikhawatirkan pada satu waktu akan menimbulkan konflik kepentingan penggunaan ruang, oleh karena itu pendayagunaan sumber daya alam harus diimbangi dengan pengelolaan dan pelestarian lingkungan hidup, penataan ruang merupakan salah satu alat untuk mengadakan kegiatan tersebut di atas, agar tercapai 
pembangunan yang berwawasan lingkungan dengan tetap memperhatikan rencana tata ruang wilayah yang bersangkutan, agar tercapai pemanfaatan sumber daya alam termasuk ruang secara terpadu, optimal, dan serasi.

Sebagai tindak lanjut dari itu, maka pemerintah membuat UndangUndang Nomorr 26 Tahun 2007 tentang Penataan Ruang, dengan keanekaragaman ekosistemnya merupakan sumber daya yang perlu disyukuri, dilindungi dan dikelola untuk mewujudkan tujuan pembangunan nasional.

Lahirnya Undang-Undang Nomor 26 Tahun 2007 tentang Penataan Ruang membawa angin segar di negara tercinta ini. Yaitu memberikan semangat dalam membangkitkan penyelenggaraan penataan ruang. Keberadaan Undang-Undang ini juga membawa dampak signifikan terhadap pembangunan wilayah dan kota-kota di Indonesia.

Ditetapkannya Undang-Undang Nomor 26 Tahun 2007 tentang Penataan Ruang sebagai pengganti atau revisi dari Undang-Undang Nomor 24 Tahun 1992 tentang Penataan Ruang yang sudah tidak sesuai kebutuhan pengaturan penataan ruang di negara kita.
Pasal 1 angka 31 Undang-Undang N0 26 Tahun 2007 Tentang Penataan Ruang mendefinisikan Ruang Terbuka Hijau ( RTH ) sebagai area memanjang / jalur dan / atau mengelompok yang penggunaannya lebih bersifat terbuka, tempat tumbuh tanaman, baik yang tumbuh secara alamiah, maupun yang sengaja ditanam

Kota-kota besar sering kali dijadikan simbol dari sebuah kemajuan atau keberhasilan. Gedung-gedung tinggi yang menjulang menghujam langit serta pusat-pusat perbelanjaan nan megah begitu menjamur dan berlombalomba untuk menjadi landmark atau icon dari setiap kota. Bahkan disalah satu sisi ibu kota Jakarta saja bisa berdiri dua atau tiga bahkan empat pusat perbelanjaan sekaligus dengan jarak yang sangat berdekat-dekatan dan kadang bersebelahan atau berhadapan. Belum lagi kendaraan bermotor yang tumpah ruah membanjiri setiap sudut jalan ibu kota. Mulai dari sepeda motor hingga mobil dengan harga selangit bisa kita jumpai. Pendek kata jikalau kemegahan dan kemewahan yang ingin kita jumpai, maka kota-kota besar di republik ini sudah menyediakannya untuk kita.

Seiring dengan kondisi bumi yang terus memburuk akibat dari pemanasan iklim, masalah penghijauan dan 
kelestarian menjadi perhatian serius tak hanya bagi bangsa indonesia tapi juga masyarakat dunia. Menurut aturan internasional mengenai ruang terbuka hijau suatu kota harus mencapai angka 30 persen dari luas kota. Kesepakatan masyarkat internasional ini juga di amini oleh pemerintah Indonesia dengan menetapkan agar daerah perkotaan memiliki minimal $20 \%$ dari luas kawasan perkotaannya untuk ruang publik ini.

Ada beberapa definisi yang menjelaskan tentang apa yang dimaksud dengan ruang terbuka hijau ini, yang dikemukakan oleh para pakar. Menurut Roger Trancik, seorang pakar dibidang Urban Design, ruang terbuka hijau adalah ruang yang didominasi oleh lingkungan alami di luar maupun didalam kota, dalam bentuk taman, halaman, areal rekreasi kota dan jalur hijau. Sementara menurut Rooden Van FC dalam Grove dan Gresswell,1983, ruang terbuka hijau adalah Fasilitas yang memberikan kontribusi penting dalam meningkatkan kualitas lingkungan permukiman, dan merupakan suatu unsur yang sangat penting dalam kegiatan rekreasi.

Pemerintah Indonesia juga mengeluarkan definisi tentang ruang terbuka hijau ini dengan istilah ruang terbuka hijau kawasan perkotaan atau RTHKP. Jikalau mengacu pada
Peraturan Mendagri Nomor 1 tahun 2007 tentang penataan ruang terbuka hijau kawasan perkotaan ini, maka pengertian Ruang Terbuka Hijau adalah bagian dari ruang terbuka suatu kawasan perkotaan yang diisi oleh tumbuhan dan tanaman guna mendukung manfaat ekologi, sosial, budaya, ekonomi dan estetika.. Ruang terbuka hijau itu sendiri terbagi atas dua jenis, yaitu RTHKP Publik dan RTHKP Privat. RTHKP Publik adalah RTHKP yang penyediaan dan pemeliharaannya menjadi tanggung jawab Pemerintah Kabupaten/Kota. Sementara RTHKP Privat adalah RTHKP yang penyediaan dan pemeliharaannya menjadi tanggung-jawab pihak/lembaga swasta, perseorangan dan masyarakat yang dikendalikan melalui izin pemanfaatan ruang oleh Pemerintah Kabupaten/Kota, kecuali Provinsi DKI Jakarta oleh Pemerintah Provinsi.

Berdasarkan jenisnya RTHKP meliputi taman kota, taman wisata alam, taman rekreasi, taman lingkungan perumahan dan permukiman, taman lingkungan perkantoran dan gedung komersial, taman hutan raya, hutan kota, hutan lindung, bentang alam seperti gunung, bukit, lereng dan lembah, cagar alam, kebun raya, kebun binatang, pemakaman umum, lapangan olah raga, lapangan upacara, parkir 
terbuka, lahan pertanian perkotaan, saluran udara tegangan tinggi (SUTT dan SUTET), sempadan sungai, pantai, bangunan, situ dan rawa, jalur pengaman jalan, median jalan, rel kereta api, pipa gas dan pedestrian, kawasan dan jalur hijau, daerah penyangga (buffer zone) lapangan udara dan taman atap (roof garden).

Seperti yang kita tahu, pembangunan fisik berupa gedunggedung megah dikota-kota memang membanggakan, namun disisi lain, pembangunan tersebut sering menggeser atau bahkan menghilangkan ruang-ruang hijau yang ada. Kita sering menjumpai taman-taman kota yang disulap menjadi gedung perkantoran atau apartement, hal ini menimbulkan dampak yang negatif bagi lingkungan yaitu ketidak seimbangan ekologi dan mempercepat proses pemanasan global yang tentunya berdampak pada kesehatan manusia cepat atau lambat. Kondisi ini terjadi akibat hilangnya pepohonan yang rimbun atau lahanlahan hijau yang ada di kota. Termasuk juga masalah polusi udara yang akan mengganggu terhadap pernafasan. Sebagai gambaran, kendaraankendaraan di jalan raya, akan mengeluarkan senyawa karbon yang terdiri dari $\mathrm{CO}$ (karbon monoksida), $\mathrm{HC}$ (hidrokarbon), dan NOx (nitrogen oksida) yang masuk ke udara dan terhirup oleh manusia. Senyawasenyawa ini sangat berbahaya bagi kesehatan manusia. Dan pepohonan yang menjadi filter udara telah hilang diganti dengan beton-beton, mengakibatkan jutaan racun akan terhirup masuk ke dalam tubuh.

Ruang-ruang ini juga mempunyai fungsi yang tak kalah penting dari masalah lingkungan hidup tapi juga berfungsi sosial dimana masyarakat bisa berkumpul dan bersantai bersama sanak keluarga atau kawan. Dengan hilangnya lahan-lahan seperti ini dari peta kota maka berdampak secara tidak langsung bagi proses-proses tersebut bahkan bukan tidak mungkin dapat menciptakan generasi yang individualistis kelak di kemudian hari karena tiadanya lagi ruang yang berfungsi untuk interaksi sosial bagi masyarakat.

Soal RTH sebetulnya sudah menjadi amanat undang-undang tentang penataan ruang yang setidaknya 30 persen. Namun, di kota-kota besar saat ini rata-rata luasan RTH masih di bawah 10 persen, bahkan ada yang masih di bawah 3 persen. Padahal selain fungsi lingkungan dan penghijauan, RTH dalam kehidupan perkotaan memiliki fungsi spesial. RTH bisa menjadi prasarana publik terkait dengan 
pendidikan luar ruang dan meningkatkan social capital (hubungan dan komunikasi antar warga). Lihat, sekarang anak-anak hanya terbiasa berekreasi di dalam ruang seperti mal yang sifatnya inward looking). jika banyak RTH dipertahankan, masyarakat dari usia anak-anak sampai dewasa, bahkan lanjut usia (lansia) akan bisa dan biasa melakukan kegiatan luar ruang, seperti olah raga, rekreasi dan melakukan kegiatan sosial di tamantaman kota. Masalahnya, lanjut dia, pemerintah kota punya keterbatasan anggaran untuk membebaskan lahan yang akan dialihfungsikan untuk RTH. Tapi yang terpenting dalam kasus-kasus semacam ini adalah penegakan hukum. Masyarakat dan konsumen juga perlu pemberdayaan sehingga memahami hak-hak mereka sebagai warga dan penghuni kota untuk mendapatkan ruang publik.

Pengamat lingkungan, Trisno Widodo, mengatakan bahwa idealnya sebuah kota mempunyai RTH sekitar 40 persen dari seluruh luas wilayah. Bila ditinjau dari segi hidrologis, RTH sangat penting untuk menunjang peresapan air hujan ke dalam tanah. Dengan cara ini, kata dia, diharapkan suplesi air tanah, khususnya air tanah dangkal oleh air hujan, semakin bertambah sehingga kekurangan akan air dapat dihindari. Hal ini sekaligus juga dapat mengurangi penyusupan air laut, apabila suplesi air hujan ke dalam tanah seimbang dengan eksploitasi air tanah tersebut.

Namun, bagi kota-kota besar di Indonesia, untuk memperluas areal resapan hujan dengan menambah ruang terbuka hijau sangat sulit. Hal tersebut disebabkan tata guna Iahan yang selalu berubah-ubah.

Ruang Terbuka Hijau sejatinya ditujukan untuk menjaga keserasian dan keseimbangan ekosistem lingkungan perkotaan dan mewujudkan kesimbangan antara lingkungan alam dan lingkungan buatan di perkotaan serta meningkatkan kualitas lingkungan perkotaan yang sehat, indah, bersih dan nyaman. Ruang terbuka hijau juga berfungsi sebagai pengamanan keberadaan kawasan lindung perkotaan, pengendali pencemaran dan kerusakan tanah, air dan udara, tempat perlindungan plasma nuftah dan keanekaragaman hayati dan pengendali tata air serta tak ketinggalan sebagai sarana estetika kota. Keberadaan ruang ini tak hanya menjadikan kota menjadi sekedar tempat yang sehat dan layak huni tapi juga nyaman dan asri.

Ruang terbuka hijau membawa begitu banyak manfaat yang terkandung. Mulai dari sarana untuk mencerminkan identitas daerah, 
menumbuhkan rasa bangga dan meningkatkan prestise daerah, sarana ruang evakuasi untuk keadaan darurat, sebagai sarana penelitian, pendidikan dan penyuluhan, memperbaiki iklim mikro hingga meningkatkan cadangan oksigen di perkotaan dan tak ketinggalan bermanfaat bagi meningkatkan nilai ekonomi lahan perkotaan. Bahkan terkandung pula manfaat yang lebih bernilai sosial seperti sebagai sarana rekreasi aktif dan pasif serta interkasi sosial atau sebagai sarana aktivitas sosial bagi anak-anak, remaja, dewasa dan manula. Bisa dibilang kebutuhan akan adanya ruang semacam ini di kota-kota besar tak hanya sekedar perlu namun kebutuhan.

$\mathrm{Di}$ dalam melakukan pembangunan, setiap Pemerintah Daerah memerlukan perencanaan yang akurat serta diharapkan dapat melakukan evaluasi terhadap pembangunan yang dilakukannya. Seiring dengan semakin pesatnya pembangunan bidang ekonomi, maka terjadi peningkatan permintaan data dan indikator-indikator yang menghendaki ketersediaan data sampai tingkat Kabupaten/ Kota. Data dan indikatorindikator pembangunan yang diperlukan adalah yang sesuai dengan perencanaan yang telah ditetapkan.
Struktur

perencanaan

pembangunan di Indonesia berdasarkan hirarki dimensi waktunya berdasarkan Undang-Undang Nomor 25 Tahun 2004 tentang Sistem Perencanaan Pembangunan Nasional dibagi menjadi perencanaan jangka panjang, jangka menengah dan jangka pendek (tahunan), sehingga dengan UndangUndang ini kita mengenal satu bagian penting dari perencanaan wilayah yaitu apa yang disebut sebagai rencana pembangunan daerah, yaitu Rencana Pembangunan Jangka Panjang Daerah (RPJP-D), Rencana Pembangunan Jangka Menengah Daerah (RPJM-D) dan Rencana Kerja Pemerintah Daerah (RKPD) serta Rencana Strategis Satuan Kerja Perangkat Daerah (RenstraSKPD) dan Rencana Kerja Satuan Kerja Perangkat Daerah (Renja-SKPD) sebagai kelengkapannya.

Perencanaan pembangunan daerah seperti diamanatkan oleh Undang-Undang Nomor 25 Tahun 2004 tentang SPPN, mewajibkan daerah untuk menyusun Rencana Pembangunan Jangka Panjang yang berdurasi waktu 20 (dua puluh) tahun yang berisi tentang visi, misi dan arah pembangunan daerah. Perencanaan ini kemudian dijabarkan dalam Rencana Pembangunan Jangka Menengah Daerah yang berdurasi waktu 5 (lima) 
tahun, yang memuat kebijakan keuangan daerah, strategi pembangunan daerah, kebijakan umum, program SKPD dan lintas SKPD, program kewilayahan disertai dengan rencana-rencana kerja dalam kerangka regulasi dan kerangka pendanaan yang bersifat indikatif. Selanjutnya RPJM Daerah dijabarkan dalam perencanaan berdurasi tahunan yang disebut sebagai Rencana Kerja Pemerintah Daerah (RKPD) yang memuat rancangan kerangka ekonomi daerah, prioritas pembangunan daerah, rencana kerja, dan pendanaannya, baik yang dilaksanakan langsung oleh pemerintah maupun yang ditempuh dengan mendorong partisipasi masyarakat.

Berkaitan dengan perencanaan pembangunan Ruang Terbuka Hijau merupakan salah satu amanat dari Pasal 1 butir 31 Undang-Undang Nomor 26 Tahun 2007 tentang Penataan Ruang mengatur tentang istilah ruang terbuka hijau yang mengandung pengertian sebagai suatu area memanjang/jalur dan/atau mengelompok yang gunanya lebih bersifat terbuka, tempat tumbuh tanaman, baik yang tumbuh secara alamiah maupun yang sengaja ditanam. Klasifikasi Ruang Terbuka Hijau berdasarkan Pasal 6 Peraturan Menteri
Dalam Negeri Nomor 1 Tahun 2007 dapat dibagi menjadi :

1. taman kota

2. taman wisata alam

3. taman rekreasi

4. taman lingkungan perumahan dan pemukiman

5. taman lingkungan perkantoran dan gedung komersial

6. taman hutan raya

7. hutan kota

8. bentang alam seperti gunung, bukit. Lereng dan lembah

9. cagar alam

10. kebun raya

11. kebun binatang

12. pemakaman umum

13. lapangan olah raga

14. lapangan upacara

15. parkir terbuka

16. tanah pertanian perkotaan

17. jalur di bawah tegangan tinggi (SUTT dan SUTET)

18. sempadan sungai, pantai, bangunan, situ dan rawa

19.jalur pengamanan jalan, median jalan, rel kereta api, pipa gas dan pedestrian

20. kawasan dan jalur hijau

21. daerah penyangga (buffeer zone) lapangan udara, dan

22. taman atap (roof garden)

23. Kawasan hijau hutan kota

Makna mengikat berarti memiliki 
akibat hukum bahwa Pemerintah Daerah harus melaksanakan seluruh perintah peraturan yang lebih tinggi derajatnya yang terdapat dalam Undang-Undang Nomor 12 Tahun 2011 tentang Pembentukan Peraturan Perundang-Undangan tersebut. Terkait dengan prinsip negara hukum dimana tujuan utama dari suatu negara adalah terwujudnya supremasi hukum (supremacy of law), dimana untuk mewujudkannya salah satunya adalah dengan melaksanakan selurut peraturan perundang-undangan sebagai tolak ukur moral dan yuridis. Dengan demikian, dalam menentukan Ruang Terbuka Hijau Kota harus mengikuti ketentuan yang berlaku.

Seperangkat aturan hukum hadir agar tercipta suatu kondisi yang damai dan tenteram. Bagaimana peranan hukum sebagai sarana penata masyarakat memilki banyak faktor. Salah satunya adalah sumber dari mana hukum tersebut berasal dan dapat mengikat.

Peraturan Menteri Dalam Negeri Nomor 1 Tahun 2007 tentang Penataan Ruang Terbuka Hijau Perkotaan merupakan aturan hukum yang berlaku dan menjadi pedoman bagi Pemerintah Daerah berkaitan dengan kewajibannya untuk menindaklanjuti aturan yang dikeluarkan oleh Pemerintah Pusat sebagai kepanjangan tangannya dalam rangka melindungi masyarakatnya dalam hal ini berkaitan dengan pengelolaan lingkungan perkotaan agar terhindar dari berbagai dampak yang ditimbulkan dari aktifitas perkotaan yang sibuk dan kompleks permasalahan lingkungan hidupnya.

Lingkungan sebagai sumber daya merupakan aset yang dapat diperlukan untuk menyejahterakan masyarakat. Hal ini sesuai dengan perintah Pasal 33 ayat (3) Undang-Undang Dasar 1945 yang menyatakan bahwa, bumi, air, dan kekayaan alam yang terkandung di dalamnya dipergunakan untuk sebesarbesarnya kemakmuran rakyat. Dengan demikian, menurut Otto Soemarwoto, sumber daya lingkungan mempunyai daya regenerasi dan asimilasi yang terbatas. Selama eksploitasi atau permintaan pelayanan ada di bawah batas daya regenerasi atau asimilasi, sumber daya terbarui itu dapat digunakan secara lestari. Akan tetapi, apabila batas itu dilampaui, sumber daya itu akan mengalami kerusakan dan fungsi sumber daya itu sebagai faktor produksi dan konsumsi atau sarana pelayanan akan mengalami gangguan.

Kondisi lingkungan hidup di kotakota banyak tercemar disebabkan aktifitas masyarakat perkotaan itu sendiri seperti asap dari aktifitas 
kendaraan bermotor, aktifitas pabrikpabrik, sehingga dengan adanya ruang terbuka hijau perkotaan dapat dijadikan sebagai pengamanan keberadaan kawasan lindung perkotaan, pengendali pencemaran dan kerusakan tanah, air dan udara, tempat perlindungan plasma nuftah dan keanekaragaman hayati dan pengendali tata air serta tak ketinggalan sebagai sarana estetika kota.

Ruang terbuka hijau juga membawa begitu banyak manfaat yang terkandung. Mulai dari sarana untuk mencerminkan identitas daerah, menumbuhkan rasa bangga dan meningkatkan prestise daerah, sarana ruang evakuasi untuk keadaan darurat, sebagai sarana penelitian, pendidikan dan penyuluhan, memperbaiki iklim mikro hingga meningkatkan cadangan oksigen di perkotaan dan tak ketinggalan bermanfaat bagi meningkatkan nilai ekonomi lahan perkotaan. Bahkan terkandung pula manfaat yang lebih bernilai sosial seperti sebagai sarana rekreasi aktif dan pasif serta interkasi sosial atau sebagai sarana aktivitas sosial bagi anak-anak, remaja, dewasa dan manula. Bisa dibilang kebutuhan akan adanya ruang semacam ini di kota-kota besar tak hanya sekedar perlu namun kebutuhan.

\section{KESIMPULAN}

Peraturan Menteri Dalam Negeri omor 1 Tahun 2007 sesuai dengan Peraturan Pemerintah Nomor 15 Tahun 2010 Jo. Undang-Undang Nomor 26 Tahun 2007 tentang Penataan Ruang Tersedianya Ruang Terbuka Hijau Kawasan Perkotaan, artinya bahwa baik Pemerintahan Propinsi maupun Pemerintahan Kabupaten/Kota harus memiliki ketaatan hukum terhadap perintah dari Peraturan yang derajatnya lebih tinggi. Hal ini apabila dihubungkan dengan keberadaan Ruang Terbuka Hijau Kawasan Perkotaan dari mulai tingkat peraturan daerah, perencanaan, pelaksanaan, dan pengendalian kawasan perkotaan untuk menyediakan ruang terbuka hijau sesuai ketentuan peraturan perundang-undangan yaitu setiap pemerintahan Kabupaten/Kota wajib menyediakan kawasan terbuka hijau kawasan perkotaan yang ideal adalah $30 \%$ dari luas wilayah. Hampir disemua kota besar di Indonesia, Ruang terbuka hijau saat ini baru mencapai $10 \%$ dari luas kota.

\section{DAFTAR PUSTAKA}

Budihardjo, Eko, \& Djoko Sujarto, Kota Berkelanjutan, Alumni, Bandung, 1999.

Budi Sudjiono dan Doddy Rusdianto, Manajemen Pemerintahan Federal, 
Citra Mandala Pratama, Jakarta, 2003.

Daniel Murdiyarso, Konvensi Perubahan Iklim, Kompas, Jakarta, 2003.

Dardak, Hermanto, Peran Penataan Ruang Dalam Mewujudkan Kota Berkelanjutan di Indonesi, Direktorat Jenderal Penataan Ruang-Departemen Pekerjaan Umum, 2006.

Daud Silalahi, Hukum Lingkungan dalam Sistem Penegakan Hukum Lingkungan Indonesia, Alumni Edisi Revisi, Bandung, 1996.

Emil Salim, Pembangunan Berwawasan Lingkungan, LP3ES, Cetakan Keenam, Jakarta, 1993.

-------, Lingkungan Hidup dan Pembangunan, Mutiara Sumber Widya, Cetakan 10, Jakarta, 1995.

Hasni, Hukum Penataan Ruang dan Penatagunaan Tanah, PT Rajagrafindo Persada, Jakarta, 2008.

Hermin Hediati Koeswadji, Hukum Pidana Lingkungan, Citra Adotya Bakti, Bandung 1993.

Jonni Purba, Pengelolaan Lingkungan Sosial, Yayasan Obor Indonesia dan Kantor Menteri Lingkungan Hidup, Jakarta, 2005.

Koesnadi Hardjosoemantri, Hukum Tata Lingkungan, Gadjah Mada University Press, Cetakan ke tujuh, Yogyakarta, 1993.
Noer Pauzi, Otonomi Daerah Sumber Daya Alam Lingkungan, Lipera Pustaka Utama. Jakarta, 2003.

Otto Soemarwoto, Hukum Lingkungan, Bina Cipta, Bandung 1997.

Rustam Hakim, Arsitektur Lansekap,Manusia, Alam dan Lingkungan, penerbit Bina Aksara Jakarta, 2004

Siti Sundari Rangkuti, Hukum Lingkungan dan Kebijaksanaan Lingkungan Nasional, Airlangga University Press, Surabaya, 2000. 
